\title{
Lactobacillus jensenii sp.nov., a New Representative of the Subgenus Thermobacterium
}

\author{
By F. GASSER,* \\ Department of Bacteriology and Immunology, \\ University of California, Berkeley, \\ California 94720, U.S.A. \\ M. MANDEL \\ Department of Biology, The University of Texas, \\ M.D. Anderson Hospital and Tumor Institute, \\ Houston, Texas, U.S.A. \\ AND M. ROGOSA \\ National Institutes of Health, National Institute of Dental Research, \\ Bethesda, Maryland, U.S.A.
}

(Accepted for publication 29 April 1970)

\section{SUMMARY}

Seven strains of homofermentative Lactobacillus newly isolated from human sources were found to possess all of the usual phenotypic characters of Lactobacillus leichmannii. However, a subsequent comparative study of the electrophoretic mobilities of their lactic dehydrogenases showed that these seven newly isolated strains were markedly different from collection strains of L. leichmannii. Determination of the mean DNA base composition of a representative sample of the new isolates $(36 \cdot \mathrm{I} \pm \mathrm{I} \cdot 2$ moles $\% \mathrm{G}+\mathrm{C})$ clearly indicates that they cannot be considered as L. leichmannii $(50 \cdot 8 \pm 0.5$ moles $\% \mathrm{G}+\mathrm{C})$. The newly isolated strains have been assigned to a new species, L. jensenii.

\section{EXPERIMENTAL AND DISCUSSION}

Seven strains of homofermentative lactobacilli isolated from human sources $(62 \mathrm{~F}, 62 \mathrm{G}, 63 \mathrm{~A}, 63 \mathrm{AA}, 63 \mathrm{AN}$ and $60 \mathrm{E}$ from vaginal discharge; 66 from a blood clot) were initially assigned to Lactobacillus leichmannii on the basis of a phenotypic comparison with the type strain ATCC 4797 (Hansen, 1968) and four other strains (ATCC 7830, ATCC 783I, NCDO LE I, NCDO LE 7) classified as L. leichmannii. With respect to the properties examined, the two groups of strains were indistinguishable (Table I) and fitted the description of L. leichmannii (Rogosa \& Sharpe, 1959).

However, in the course of a subsequent comparative study of the lactic dehydrogenases of lactobacilli by gel electrophoresis, reported in an accompanying paper (Gasser, 1970), we observed that these two groups of strains had quite different lactic dehydrogenase patterns. Since most Lactobacillus species share a well-defined species-specific pattern of lactic dehydrogenases, the observed differences suggested that the new isolates might have been incorrectly assigned to Lactobacillus leichmannii.

* Permanent address: Institut Pasteur, 25 rue du Docteur Roux, Paris (XV), France. 
This was confirmed by determinations of the mean base composition of the DNA isolated from two authentic strains of $L$. leichmannii and four of the new isolates (Table 2). In the subgenus Thermobacterium, DNA base compositions have a markedly

Table I. Phenotypic characters of authentic strains of L. leichmannii and of newly isolated strains of L. jensenii (initially identified as Lactobacillus leichmannii)

Table also includes the characters given by Rogosa \& Sharpe (1959) for L. leichmannii, L. acidophilus and $L$. jugurti. For techniques of identification, see Rogosa, Franklin \& Perry (196I)?and Gasser (1964).

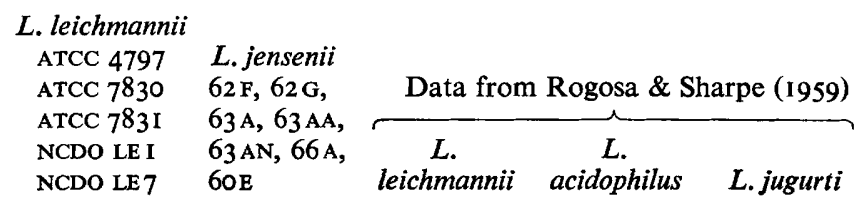

Growth at $15^{\circ}$

Lactate isomer produced

Arginine hydrolysis

Fermentation of:

Galactose

Lactose

Melibiose

Trehalose

Cellobiose

Saccharose

Maltose

Raffinose

Melezitose

Amygdalin

Esculin

Salicin

Mannitol

Sorbitol

Arabinose

Xylose

Nutritional requirements $\dagger$

Thiamine

Riboflavin

Pyridoxal

Folic acid

Vitamin $\mathrm{B}_{12}$

Nicotinic acid

Ca pantothenate

Biotin

Para-amino benzoate

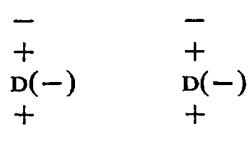

$\begin{array}{ll}- & -{ }^{*} \\ + & - \\ + & - \\ + & + \\ + & + \\ + & + \\ - & + \\ + & - \\ + & + \\ + & + \\ + & + \\ - & - \\ - & - \\ - & -\end{array}$

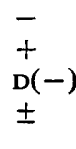

-
\pm
+
+
+
+
-
+
+
+
-
-

$\begin{array}{ll}- & - \\ + & + \\ \text { DL } & \text { DL } \\ - & -\end{array}$

$\begin{array}{ll}+ & + \\ + & + \\ \pm & - \\ + & \pm \\ + & - \\ + & - \\ + & \pm \\ \pm & - \\ + & - \\ + & - \\ + & - \\ + & - \\ - & - \\ - & - \\ - & \end{array}$

* Two strains fermented galactose slowly.

$\dagger+$ Indicates requirement; - indicates no exogenous requirement; \pm indicates variable result, depending on strain.

bimodal distribution: L. leichmannii, L. delbrueckii, L. lactis and L. bulgaricus have DNA that contains about 50.5 moles \% guanine+cytosine $(\mathrm{G}+\mathrm{C})$, whereas $L$. acidophilus and $L$. jugurti have DNA that contains about 36 to 39 moles $\% \mathrm{G}+\mathrm{C}$ (Gasser \& Mandel, I968). The average value for the new isolates examined ( $36 \cdot \mathrm{I} \pm \mathrm{I} \cdot 2$ moles $\% \mathrm{G}+\mathrm{C}$ ) clearly puts them near the L. acidophilus $-L$. jugurti group with respect 
to this character, even though they resemble $L$. leichmannii much more closely in phenotypic respects. Since they can be readily distinguished from both $L$. acidophilus and $L$. jugurti by virtue of such characters as the isomer of lactic acid produced, arginine hydrolysis and lactose-fermenting ability (Table I) it seems appropriate to recognize them as a new species, for which we propose the name $L$. jensenii, in honour of S. Orla Jensen.

Table 2. Guanine + cystosine contents of DNA isolated from authentic strains of Lactobacillus leichmannii (*) and from the newly isolated strains

Base composition of DNA determined by ultracentrifugation in $\mathrm{CsCl}$ density gradient (Mandel, I966).

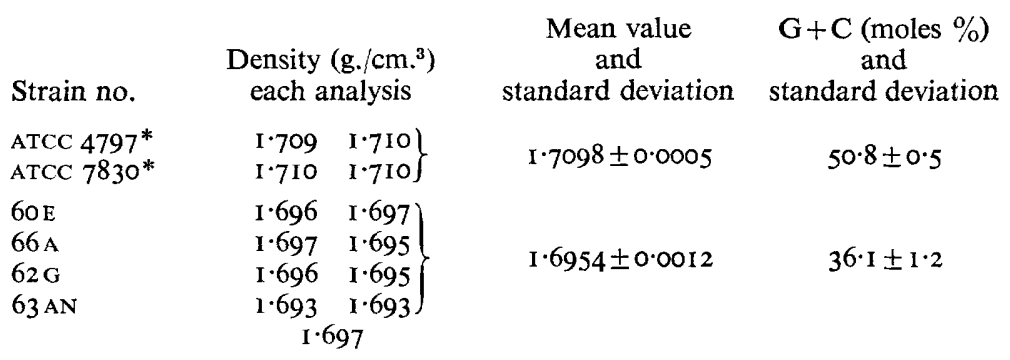

\section{Description}

Lactobacillus jensenii sp.nov.

Homofermentative, producing $\mathrm{D}(-)$ lactic acid.

Mean DNA base composition: $36 \cdot \mathrm{I} \pm \mathrm{I} \cdot 2$ moles $\% \mathrm{G}+\mathrm{C}$.

Growth at $45^{\circ}$ but not at $15^{\circ}$.

Arginine hydrolysed.

Cellobiose, sucrose, maltose amygdalin, esculin and salicin fermented; galactose, melibiose and raffinose fermented by a few strains; lactose, melezitose, mannitol, sorbitol, arabinose and xylose not fermented.

Folic acid, vitamin $B_{12}$, nicotinic acid and calcium pantothenate required for growth.

The type strain, $62 \mathrm{G}$, has been deposited in the American Type Culture Collection as strain no. 25258 and in the Collection de l'Institut Pasteur, Paris, as strain no. 6917.

This investigation was supported in part by U.S. Public Health Service grant Al-1808 from the National Institutes of Health, National Institute of Allergy and Infectious Diseases, and in part by National Science Foundation grant GB-68I6. The travel expenses of the senior author were defrayed by a Fulbright grant, P.L. 87256 .

\section{REFERENCES}

Gasser, F. (1964). Identification des Lactobacillus fecaux. Annales de l'Institut Pasteur, Paris, 1o6, $778-796$.

GASSER, F. (1970). Electrophoretic characterization of lactic dehydrogenases in the genus Lactobacillus. The Journal of General Microbiology 62, 223-239.

GASSER, F. \& MANDEL, M. (1968). Deoxyribonucleic acid base composition of the genus Lactobacillus. Journal of Bacteriology $96,580-588$.

HANSEN, P. A. (1968). Type strains of Lactobacillus species. A Report by the Taxonomic Subcommittee on Lactobacilli and Closely Related Organisms (A Subcommittee of the International Committee on Nomenclature of Bacteria of the International Association of Microbiological Societies). Rockville, Maryland: American Type Culture Collection. 
Mandel, M. (1966). Deoxyribonucleic acid base composition in the genus Pseudomonas. The Journal of General Microbiology 43, 273-292.

Rogosa, M., Franklin, J. G. \& Perry, K. D. (1961). Correlation of the vitamin requirements with cultural and biochemical characters of Lactobacillus spp. The Journal of General Microbiology 25, 473-482.

Rogosa, M. \& Sharpe, M. E. (1959). An approach to the classification of lactobacilli. The Journal of Applied Bacteriology 22, 329-340. 